ISSN 1978 - 3000

\title{
Effects of Feeding Kroto (Aerophylla smaragdina), Kricket (Brachytrypes membranaceus) and Diet Combinations on Live Performance of Young Edible - Nest Swiftlet (Collocalia fuciphaga)
}

\author{
B. Brata, R. Saepudin, Sutriyono and Lindya \\ Animal Science Department, Faculty of Agriculture, Bengkulu University \\ Jl. Raya Kandang Limun, Bengkulu 38371A-Indonesia \\ Corresponding E-mail: bratabieng@yahoo.co.id
}

\begin{abstract}
The aim of this research was to investigate the performance of young Edible-nest Swiftlet (Collocalia fuciphaga) fed (Aerophylla smaragdina), cricket (Brachytrypes membranaceus) and diet combinations of 33\% cricket, $34 \%$ kroto and $33 \%$ of commercial diet/BR1. The observation was started from the bird hatches until it fledges. Experiment design used was completely randomized design with three treatments and four replications; each of the replications consists of ten young Edible-nest Swiftlet (Collocalia fuciphaga). The treatments were $100 \%$ kroto, $100 \%$ cricket and diet combinations of of 33\% cricket (Brachytrypes membranaceus), $34 \%$ kroto and $33 \%$ of commercial diet/BR1. The variables measured were feed consumption, body weight, feed conversion and total loss. Results showed that, there were insignificant effects of feeding kroto, cricket and diet combinations of $33 \%$ cricket, $34 \%$ kroto and $33 \%$ of commercial diet/BR1 on live performance of young Edible-nest Swiftlet, observed from the bird hatches until it fledges. By the end of the observation, one young Edible-nest Swiftlet (Collocalia fuciphaga) survived.
\end{abstract}

Keywords: young edible-nest swiftlet (Collocalia fuciphaga), kroto and cricket.

\section{INTRODUCTION}

Indonesia is one of the biggest producers for Edible-nest swiftlet (Collocalia fuciphaga) with the total production of approximately 105 tones. Two out of twelve species of swiftlets are widely used; Collocalia fuciphaga and Collocalia maxima (Sawitri and Garsetiasih, 2000). The farming of the Edible-nest Swiftlet (Collocalia fuciphaga) for their nests is an important industry for a number of people all around Indonesia. Mardiastuti et al. (1999), mentioned that those species whose nests are 'white' shallow cups and made almost purely of saliva are produced by Collocalia fuciphaga.

In Bengkulu, nests of Ediblenest Swiftlet (Collocalia fuciphaga) is one of primary incomes in the society as Edible-nest swiftlet (Collocalia fuciphaga) annual production is 1.5 tones (Saepudin, 2007a) ; as well as source of district own revenue through tax collection. Moreover, Saepudin (2006) mentioned that Bengkulu is a potential area to develop Edible Nest Swiftlet (Collocalia fuciphaga) industry for its environment factors.

There are some problems in developing Edible Nest Swiftlet (Collocalia fuciphaga) farming such as inhabited buildings, a decrease of young Edible Nest Swiftlet (Collocalia fuciphaga) population and unavailability of natural food. According to Wibowo (1995), the chicks are fed with food balls 
regurgitated by mist-netted adults. After hatching, the chicks are most likely to have low live percentage; even though there are numerous researches on swiftlet diets.

In the wild life, the nestling period lasts 45 days. Once they have fledged, the young swiftlets are fully independent and are no longer fed by their parents. Furthermore, Wibowo (1995) mentioned that swiftlets food is mostly pests for the farmers. Food for young swiftlets, which is called Kroto (Aerophylla smaragdina), is available at pet shop. According to Widyaningrum et al. (2000), cricket (Brachytrypes membranaceus) a domesticated animal is a type of food for singing birds. The finding of Mardiastuti (1999) showed that feeding diet combination of insect and kroto showed a better weight gain than single diet feeding. Saepudin $(2007 b)$ revealed that feeding edible-Nest Swiftlet (Collocalia fuciphaga) nests given (15\%) on diet had better liveperformance compared to $10 \%$ and $5 \%$ Edible Nest Swiftlet (Collocalia fuciphaga) nests on diet.

The aim of the research was to find out the performance of young Edible Nest Swiftlet (Collocalia fuciphaga) fed kroto (Aerophylla smaragdina), cricket (Brachytrypes membranaceus) and diet combinations. It was hypothesized that the feeding treatments would be able to improve live performance as well as survival of the bird after hatching until it fledges.

\section{MATERIAL AND METHODS}

The research was conducted in bird nest building at Sukamerindu of Sungai Serut district, Bengkulu and Animal Science Laboratory started from December, 2007 to January, 2008.

The young edible - Nest Swiftlet and the diet were weighed by using Oertling analytical balance to the nearest $0.01 \mathrm{~g}$. Artificial nests were used to nestle young edibleNest Swiftlet. A modified humidifier was made of fan and plastic. Foam was used to put the hatched chicks, forceps were to select and place feed inside the mouth of the bird. Termohygrometer was used to measure the air temperature and humidity. There were also lamps and three units of electric hen hatch used.

Materials used were 120 young edible-nest Swiftlet, kroto, cricket and diet combinations of $33 \%$ cricket, $34 \%$

Table 1. Nutritional value of the diet

\begin{tabular}{|c|c|c|c|c|c|}
\hline \multirow{2}{*}{ Nutrient } & \multirow{2}{*}{$\begin{array}{l}\text { Kroto } \\
(100 \%)\end{array}$} & \multirow{2}{*}{$\begin{array}{l}\text { Cricket } \\
(100 \%)\end{array}$} & \multicolumn{2}{|c|}{ Combination } & \multirow[b]{2}{*}{ BRI $(33 \%)$} \\
\hline & & & Cricket $(33 \%)$ & Kroto $(34 \%)$ & \\
\hline Protein & $11.09^{*}$ & $60.47^{* *}$ & & 30.99 & \\
\hline Energy & $3059.10^{*}$ & $6172.88^{* *}$ & & 4073.74 & \\
\hline Crude fiber & $2.06^{*}$ & $7.30^{* *}$ & & 4.76 & \\
\hline Calcium & 0.26 & 2.20 & & 1.94 & \\
\hline Phosphor & 0.29 & 0.62 & & 0.94 & \\
\hline Crude fat & $0.71^{*}$ & $8.20^{* *}$ & & 6.20 & \\
\hline
\end{tabular}

62 | Feeding of Young Edible - Nest Swiftlet (Collocalia fuciphaga) 
kroto and $33 \%$ of commercial diet/BR1. Stimulant perfume made 1 $\mathrm{g}$ of edible-nest Swiftlets nests and 1 litter.of water. Besides this, another of the material was $96 \%$ alcohol (Rasemut and Rafiko (pesticides).

The electric hatch machine was set up a day before the research to stabilize the temperature. The ideal temperature was maintained at $37^{\circ} \mathrm{C}$ and $70 \%$ of humidity, then the machine is ready to use.

The birds were transferred from the electric hen hatch to a suitable sized box. . The rearing room was sterilized by using pesticides (Arcoa and Rasemut) and sprayed by using $96 \%$ of alcohol. Rearing room was then spayed with stimulant perfume. The room was equipped with brooder and the temperature was set from 26 to $29^{\circ} \mathrm{C}$ and 80 to $90 \%$ of humidity. After two weeks, the young edible-nest Swiftlet was transferred to artificial nests attached to the wall of the bird nest building.

Nutritional value of diet is presented in Table 1 . The young edible-nest Swiftlets were fed with kroto, cricket and diet combinations of $33 \%$ cricket, $34 \%$ kroto and $33 \%$ of commercial diet/BR1. Kroto was sorted to separate the old ones and made free of dirt, and then boiled for fifteen minutes. The crickets were removed for legs and heads and then put under warm water and grinded finely. The diets were then mixed.

Experiment design used was completely randomized design with three treatments and four replications; each of the replications consists of ten young Edible-nest
Swiftlet-The treatments were 100\% kroto, $100 \%$ cricket and diet combinations of of $33 \%$ cricket, $34 \%$ kroto and $33 \%$ of commercial diet/BR1.

Collected data were analyzed by using Analysis of variance (ANOVA). Any significant difference among treatments was tested by using Duncan's Multiple Range Test (DMRT).

There were thirteen times of feeding or whenever there was a sign of hunger and feeding was stopped when the young Edible-nest Swiftlet closed its mouth.

Feed consumption of young Edible-nest Swiftlet was the total feed given minus the feed available at the end of the day. The average feed consumption was measured weekly (gram/bird). Feed conversion was measured as total feed consumption divided by weight gain.

\section{RESULTS AND DISCUSSION}

\section{Feed Consumption}

The average of feed consumption on day $1^{\text {st }}$ to $21^{\text {st }}$ is shown in Table 2. The results showed that the feeding treatments did not significantly affect feed consumption $(\mathrm{P}>0.05)$. However, the Table 2 showed that treatment of feeding diet combinations gave the highest feed consumption (25.65 g/bird) compared to cricket (23.22 $\mathrm{g} / \mathrm{bird})$ and kroto (20.68 g/bird).

The feed consumption of diet combinations is the highest among treatments. It indicated that the 
Table 2. The average of feed consumption, weight gain, and feed conversion on day $1^{\text {st }}$ to $21^{\text {st }}$

\begin{tabular}{lccc}
\hline \multicolumn{1}{c}{ Variable } & \multicolumn{3}{c}{ Average } \\
\cline { 2 - 4 } & Kroto & Cricket & Diet Combination \\
\hline Feed Consumption & $20.68 \pm 2.57 \mathrm{a}$ & $23.22 \pm 1.04 \mathrm{a}$ & $25.65 \pm 3.78 \mathrm{a} \mathrm{ns}$ \\
Weight gain & $2.45 \pm 0.26 \mathrm{a}$ & $2.64 \pm 0.16 \mathrm{a}$ & $2.72 \pm 0.15 \mathrm{a} \mathrm{ns}$ \\
Feed conversion & $8.43 \pm 0.30 \mathrm{a}$ & $8.81 \pm 0.44 \mathrm{a}$ & $9.45 \pm 1.40 \mathrm{a} \mathrm{ns}$ \\
\hline \multicolumn{4}{l}{ Figures with different letters indicate the group mean is significantly different $(\mathrm{P}<0.005)$ The data are show as mean $\pm \mathrm{SEM}$}
\end{tabular}

variations of feed given affected the amount of feed intake. Therefore, diet combinations can be an alternative method of feeding for young Ediblenest Swiftlet. Moreover, the highest feed consumption on combination diet treatment group was due to a balance energy and protein content (Table 1)

Yangesa (1997) revealed that young Edible-nest Swiftlet in wild life obtains feed of feed balls regurgitated by mist-netted adults, on average, contained 1500 to 2000 tiny insects. As insects, they have chitin which is indigestible, it is digested by adult saliva; which is not well developed in young bird (Mardiastuti, 1999).

\section{Body Weight Gain of Edible-nest Swiftlet (Collocalia fuciphaga)}

The average of weight gain on day $1^{\text {st }}$ to $21^{\text {st }}$ is shown in Table 2 . The results of statistical analysis showed that the feeding treatments did not significantly affected average of weight gain $(P>0.05)$. Insignificance of weight gain among feeding treatments may be due to the diet combinations. Saepudin (2007b) revealed that feeding edible-Nest Swiftlet (Collocalia fuciphaga) nests $(15 \%)$, which was mixed in diet gave better live performance of young edible Nest Swiftlet.

The combination of diet treatment perform the highest body weight gain $(2.72 \mathrm{~g} / \mathrm{bird})$, compared to that of in cricket group $(2.64 \mathrm{~g} / \mathrm{bird})$ and kroto treatment group $(2.45 \mathrm{~g} / \mathrm{bird})$ The highest weight gain on combination diet treatment group was due to a balance energy and protein content (see Table 1). Compare to energy and protein contents in kroto and cricket, it is clear that combination of kroto, cricket and BR1 had more balance energy and protein content. Moreover, the balance calcium and phosphor in combination diet treatment (Table 1) might cause the body weight gain compared to the one in calcium and phosphor in kroto and cricket.

Saepudin (2007c) stated feeding diet combination of kroto $(50 \%)$ and feeding edible-Nest Swiftlet (Collacalia fuchiphaga) $(50 \%)$ might cause body weight gain better compared to kroto $(100 \%)$ and feeding edible-Nest Swiflet (Collacalia fuchiphaga) (100\%).

\section{Feed Conversion}

The average of feed conversion is shown in Table 2. The results of statistical analysis showed that the feeding treatments did not significantly affect feed conversion $(P>0.05)$. Insignificance of feed conversion among feeding treatments indicated that the diets may have similar efficiency values. It is worth 
noting that kroto had a lower feed conversion (8.83) compared to cricket (9.81).

Feed conversion indicates the level of food utilization efficiency. Kroto seemed to be the most efficient diet for young edible-Nest Swiftlet among the treatments groups. The high efficiency of kroto was due to the lowest feed consumption contributed to better weight gain (Table 2). This means that the combination of low protein $(11.09 \%)$ and low energy (3059.10 kcal) made this diet being the most efficient with feed conversion was 8.43 .

\section{Live young edible-Nest Swiftlet (Collocalia fuciphaga) that fledges}

The number of live edible-nest swiftlet that fledges is shown in Table 3 . In the Table 3 , showed that, there are different numbers of live ediblenest swiftlet until [fourth] week. In kroto treatment group, there were 7 birds, in cricket treatment group were 4 birds and combination treatment group were 6 birds. In the end of the research period (week-8), there was only one young edible-Nest Swiftlet fledges; which was in cricket feeding treatment group. Survival and livability of young edible nest swiftlet on cricket treatment group was the best of all treatments at the end of the research period. This might be caused of the level of protein in cricket was the most suitable to support live (60.90\%). According to Nugroho and Sukma (2003), young Edible-nest Swiftlet requires $55-60 \%$ protein to grow well.

As a matter of fact, swifts are insectivores. Adriana (1999) reported that swifts frequently feed on Hymenoptera, Dyptera, Hemiptera and Hymenoptera. In Penang Malaysia, $40.8 \%$ of $100-1200$ insects eaten by swifts are Hymenoptera. Moreover, Nugroho et al. (1991) revealed that edible-nest swiftlet (Collocalia fuciphaga) requires 1000 to 5000 insects per day.

\section{CONCLUSION}

In conclusion, kroto, cricket and combinations diet had a non significant effect on feed consumption, body weight gain, feed consumption and the number of live edible-nest swiftlet that fledges. However, there was one live ediblenest swiftlet that fledges in cricket treatment group.

Table 3. The number of live edible-nest swiftlet that fledges

\begin{tabular}{cccc}
\hline \multirow{2}{*}{ Week } & \multicolumn{3}{c}{ Number of edible-nest swiftlet that fledges } \\
\cline { 2 - 4 } & Kroto & Cricket & Diet combinations \\
\hline 1 & 25 & 21 & 21 \\
2 & 17 & 10 & 15 \\
3 & 11 & 7 & 6 \\
4 & 7 & 4 & \\
5 & & 1 & \\
6 & & 1 & \\
7 & & 1 & \\
8 & & $1^{*}$ & \\
$*$ * live edible-nest swiftlet that fledges & &
\end{tabular}




\section{ACKNOWLEDGEMENT}

The author greatest thank to Higher Education that has funded the research through A2 Research Grant 2007 of Animal Science Department, Faculty of Agriculture, University of Bengkulu with contract No: 03/A2/JPT/2007

\section{REFERENCES}

Andriana, B. B. 1999. Makanan burung wallet (Collocalia fuciphaga) rumahan di Kragilan Media Konservasi. Jurnal Ilmiah Bidang Konservasi Sumberdaya Alam Hayati dan Lingkungan. VI(2) :5153

Farida, W. R., K. K. Wardani., A. S. Tjakradidjaja, and D. Diapari. 2008. Konsumsi dan penggunaan pakan pada Tarsius (Tarsius bancanus) Betina di Pengakaran. Biodiversitas. 9(2) : 148-151

Mardiastuti, A. 1999. An attempt artificially incubate and raise chicks of edible-nest swiftlets. Media Konservasi. Jurnal Ilmiah Bidang Konservasi Sumberdaya Alam Hayati dan Lingkungan. $\mathrm{VI}(2): 45-49$

Mardiastuti., A. Djanglot, Y. A. Mulyani, and A. Nugraha.1999. Pengelolaan pasca panen sarang burung wallet. Media Konsevasi. Jurnal Ilmiah Bidang Konservasi Sumberdaya Alam Hayati dan Lingkungan. $\mathrm{VI}(2): 69-72$

Nugroho, E. W. I., S.S Whendrato, and I.M. Madyana. 1991. Budidaya Walet di Malaysia. Eka Offset, Semarang.

Nugroho, H. K. and E. S. Sukma. 2003 Sarana Budidaya Walet. Penebar Swadaya, Jakarta.
Saepudin, R. 2006. Studi habitat makro burung walet (Collocalia sp) di Kota Bengkulu. Jurnal Peternakan Indonesia. 1(1) : 8-16

Saepudin, R. 2007a. Pengaruh kosentrasi larutan hidrogen peroksida $\left(\mathrm{H}_{2} \mathrm{O}_{2}\right)$ terhadap derejat putih dan nilai gizi sarang burung walet sarang hitam (Collocalia maxima). Jurnal Sain Peternakan Indonesia. 2 (1) : 40-44.

Saepudin, R. 2007b. Kajian tentang penetasan telur walet (Collocalia fuciphaga). Jurnal Sain Peternakan Indonesia. 2 (2) : 73-78

Saepudin, R. 2007c. Penggunaan kroto dengan sarang walet sebagai pakan untuk meningkatkan daya tahan hidup anak walet (Collocalia fuciphaga). Jurnal Ilmu - Ilmu Pertanian. Edisi Khusus (2) : 235240

Sawitri, R and R. Garsetiasih 2000. Studi populasi, habitat serta produktivitas burung walet putih (Collocalia fuciphaga) di Gombong Selatan Jawa Tengah. Buletin Penelitian Hutan Visi dan Misi P3H \& KA. (620) : 37-49

Wibowo, S. 1995. Budidaya Sarang Walet. Penebar Swadaya, Jakarta.

Widiyaningrum, P., A. M. Fuah, D T H. Sihombing and A.

Djuhara. 2000. Pengaruh sex Rasio dan jenis pakan terhadap produksi dan daya tetas telur tiga jenis jangjrik lokal. Gryllus miratus Burn, Gryllus bimaculatus De Geer, dan Gryllus testaceus Walk (Orthoptera: Gryllide). Jurnal Ilmiah. Ilmu Perternakan, 24 (2) : 75-80.

Yangesa, I. 1997. Penetasan telur dan pemeliharaan anakan burung walet sarang putih (Collocolia fuchiphaga). Skripsi. Fakultas Kehutanan, Institut Pertanian Bogor, Bogor. 